\title{
Muuttoliikkeen suunnasta eräissä Varsinais-Suomen kunnissa vuosina $1921-1945$
}

\author{
Kirjoittanut Reino Lento.
}

Tutkimuksen tarkoitus, lähdeaineisto ja metodi. Eräässä aikaisemmin julkaistussa tutkimuksessa * on jo selvitelty muuttoliikkeen vilkkautta sekä muuttaneiden jakaantumista sukupuolen ja iän mukaan yhdeksässä Varsinais-Suomen kunnassa, Dragsfjärdissä, Paraisilla, Paimiossa, Halikossa, Karunassa, Perttelissä, Pyhämaassa, Pyhärannassa ja Mynämäellä vuosina 1921-1945. Seuraavan esityksen tarkoituksena on valaista samojen kuntien muuttoliikettä toiselta kannalta, nimittäin pitämällä silmällä muttojen pituutta ja suuntaa sekä niiden jakaantumista kaupunkien ja maaseudun kesken sanottuna ajanjaksona.

Tärkeimpänä $l a ̈ h d e a$ in e is t o n a ovat olleet seurakuntien muuttaneiden luetteloiden antamat tiedot siitä, mistä kunnasta tai mihin kuntaan kukin muutto on tapahtunut. Dragsfjärdin ja $\mathrm{Pa}-$ raisten kuntien osalta näitä tietoja on kuitenkin täyđennetty tilastollisessa päätoimistossa olevan siviilirekisteriläisiä koskevan kortiston avulla, kun siviilirekisterillä on sanotuissa kunnissa melkoinen merkitys.

* Lento, Reino, Eräiden Varsinais-Suomen kuntien muuttoliikkeestä vuosina 1921-1945. Varsinais-Suomen maakuntakirja 11. Turku 1950. 
Tutkimus jakaantuu kahteen pääosaan. Edellisessä ovat tarkastelun kohteena muuttojen lähtökohta ja määrän pää, jälkimmäisessä otetaan niiden lisäksi huomioon myös muuttaneiden s y n ty mäkunta. Seurakuntien muuttaneiden luetteloissa ei syntymäpaikkaa yleensä ole mainittu, joten sitä koskevat tiedot on pitänyt hakea kirkon pääkirjasta. Kun tämä työ on vaatinut paljon aikaa ja vaivaa, on syntymäpaikkatiedot kerätty vain 3-vuotiskausilta $1923-1925$, 1933-1935 ja $1943-1945$. Suurten Paraisten ja Halikon seurakuntien osalta on muutkin tiedot hankittu vain mainituilta yhdeksältä vuodelta. Tästä syystä jäljempänä esitettävät muuttaneiden luvut poikkeavat mainittujen kuntien osalta aikaisemmin julkaistun tutkimuksen taululiitteessä olevista luvuista, jotka perustuvat viralliseen tilastoon ja tarkoittavat koko ajanjaksoa 1921-1945. Vähäisiä eroavuuksia aiheuttaa myös se seikka, että muuttaneiden luetteloihin perustuvat luvut eivät tarkalleen pidä yhtä virallisen tilaston lukujen kanssa. ${ }^{1}$

Taloudellisten tekijöiden vaikutus muuttoliikkeeseen on pyritty tuomaan tutkimuksessa esille siten, että ko. kunnat on l u okiteltu väestönsä elinkeinoryhmityksen ym. seikkojen perusteella kolmeen päätyppiin: teollisuuskuntiin, maatalouskuntiin sekä niiden välimuotoa edustaviin sekakuntiin. Maatalouskunnat on lisäksi jaettu kahteen alaryhmään, »varsinaisiin maatalouskuntiin» ja »pienviljelyskuntiin». ${ }^{2}$ Kunnat jakaantuvat eri ryhmien kesken seuraavasti:

Teollisuuskunnat: Sekakunnat: Varsinaiset $m$ a a ta-

\section{louskunnat:}

Dragsfjärd ja Parainen

Paimio ja Halikko

Pienviljelyskunnat: Mynämäki, Pyhäranta ja Pyhämaa.

Vuonna 1898 annetussa seurakunnasta toiseen muuttoa koskevassa asetuksessa säädettiin muuttoilmoituksen laiminlyömisestä 10 markan suuruinen sakko. Se menetti kuitenkin ensimmäisen maailmansodan aikana alkaneen inflaation johdosta merkityksensä, minkä vuoksi melkoinen osa 1920-luvun muuttotapauksia 
vietiin kirjoihin vasta v. 1931, jolloin uusi, entistä ankarampi muuttokirja-asetus tuli voimaan. Mainittu vuosi on sen vuoksi liitetty tässä tutkimuksessa sitä edeltäneisiin vuosiin. Kun sotavuosi 1940 taas sopii yhteen sitä seuraavien vuosien kanssa, on tutkittava aika täten tullut jaetuksi vuosijaksoihin 1921-1931, 1932-1939 ja $1940-1945$.

\section{Muuton lähtökohta ja määränpää.}

Kuntaan ja kunnasta muutto. Taulukossa 1 on kuntaan muuttaneet jaettu neljään ryhmään sen perusteella, onko muuton lähtökohtana ollut: 1) kaupunki, 2) naapurikunta, 3) jokin mu Turun ja Porin läänin maalaiskunta tai 4) jokin muiden läänien maalaiskunta. Kunnasta muuttaneet on ryhmitelty vastaavalla tavalla. Näin saatujen absoluuttisten lukujen perusteella on sitten laskettu, suuriko prosenttimäärä muuttaneista tulee kunkin mainitun kuntaryhmän osalle. Tulokset näkyvät taulukosta 2.

Tarkastellessamme taulukossa 2 olevia kuntien yhteislukuja voimme ensinnäkin panna merkille, että s e kä kunta an et $t a ̈$ kunnasta muuttaneista yhä pienenevä prosenttimäärä on tullut naapurikuntien osalle. Turun ja Porin läänin muiden maalaiskuntien osuus suureni 1930-luvulla, mutta väheni sotavuosina, kun taas kaupunkien ja läänin ulkopuolella sijaitsevien maalaiskuntien merkitys tässä suhteessa on yhtä vähäistä poikkeusta lukuun ottamatta - jatkuvasti lisääntynyt. Voimme siis todeta, että mu ut tojen pituus on ajan mittaan kasvanut.

Sama seikka ilmenee myös taulukon 2 eri sarakkeiden keskinäisestä vertailusta. Vv. 1921-1931 suurin osa kuntaan ja kunnasta muutoista tuli naapurikuntien osalle läänin muiden maalaiskuntien ollessa tässä suhteessa toisella tilalla. 1930-luvulla kunnasta muutto suuntautui ensisijaisesti viimeksi mainittuihin kuntiin, ja sotavuosina ne olivat edellä naapurikunnista sekä kuntaan 



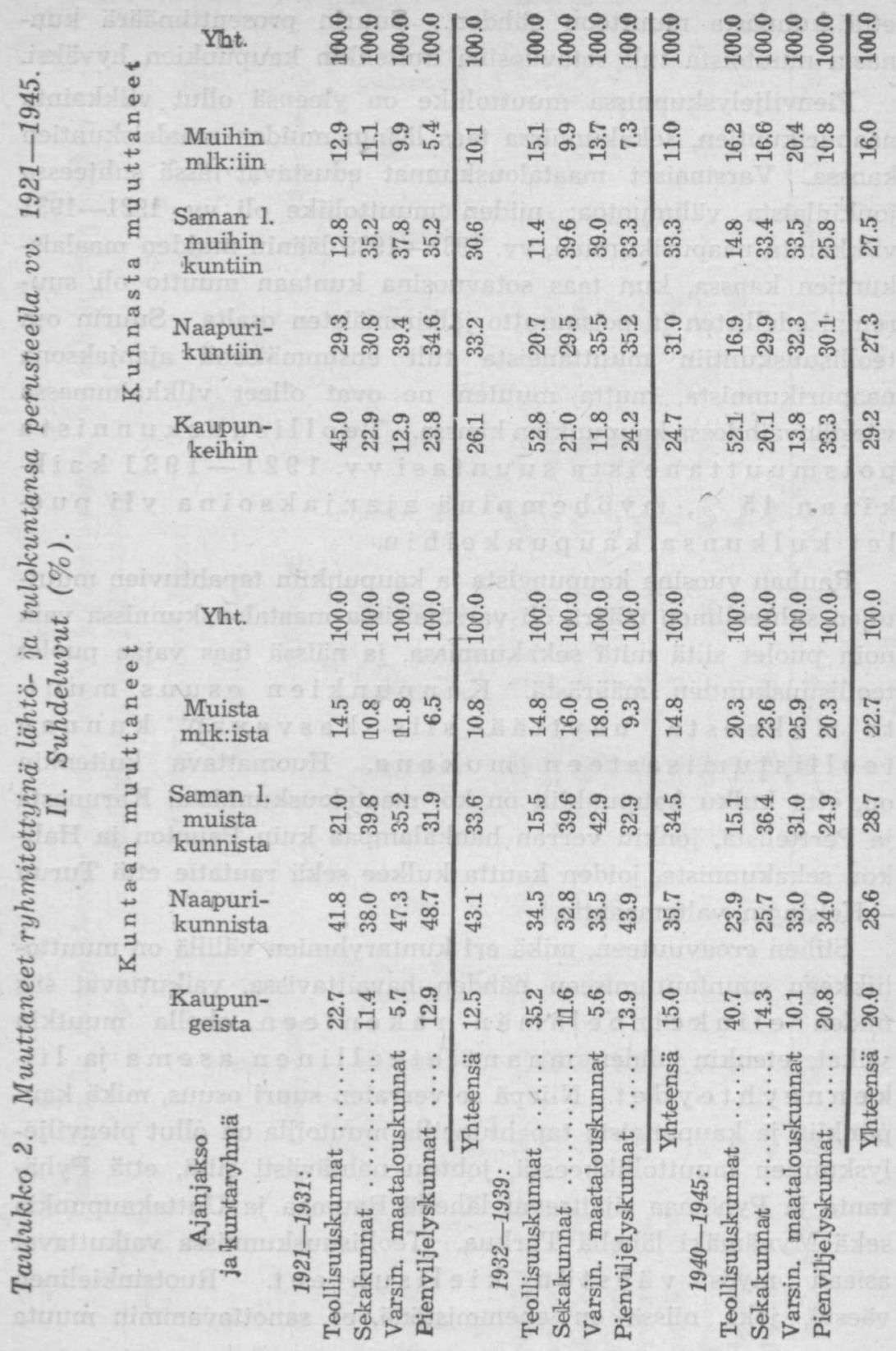


että kunnasta muuttoon nähden. Suurin prosenttimäärä kunnasta muutoista tuli sotavuosina kuitenkin kaupunkien hyväksi.

Pienviljelyskunnissa muuttoliike on yleensä ollut vilkkainta naapurikuntien, sekakunnissa taas läänin muiden maalaiskuntien kanssa. Varsinaiset maatalouskunnat edustavat tässä suhteessa jonkinlaista välimuotoa: niiden muuttoliike oli vv. 1921-1931 vilkkainta naapurikuntien, vv. 1932-1939 läänin muiden maalaiskuntien kanssa, kun taas sotavuosina kuntaan muutto oli suurempi edellisten ja poismuutto jälkimmäisten osalta. Suurin osa teollisuuskuntiin muuttaneista tuli ensimmäisenä ajanjaksona naapurikunnista, mutta muuten ne ovat olleet vilkkaimmassa väestönvaihdossa kaupunkien kanssa. Te oll is u u s k un n is t a poismuuttaneista suuntasivv. $1921-1931$ kaikkiaan $45 \%$, myöhempinä ajanjaksoina yli puolet kulkunsa kaupunkeihin.

Rauhan vuosina kaupungista ja kaupunkiin tapahtuvien muuttojen suhteellinen määrä oli varsinaisissa maatalouskunnissa vain noin puolet siitä mitä sekakunnissa, ja näissä taas vajaa puolet teollisuuskuntien määrästä. Ka u punkien osuus mu ttoliikkeestä näyttää siis kasvavan kunnan teollistumisasteen mukana. Huomattava kuitenkin on, että kulku kaupunkiin on ko. maatalouskunnista, Karunasta ja Perttelistä, jonkin verran hankalampaa kuin Paimion ja Halikon sekakunnista, joiden kautta kulkee sekä rautatie että Turun --Helsingin valtamaantie.

Siihen eroavuuteen, mikä eri kuntaryhmien välillä on muuttoliikkeen suuntautumiseen nähden havaittavissa, vaikuttavat siis niiden elinkeinoelämän rakenteen ohella muutkin seikat, etenkin niiden mantieteellinen asema ja li ikenneyhteydet. Niinpä se verraten suuri osuus, mikä kaupunkiin ja kaupungista tapahtuneilla muutoilla on ollut pienviljelyskuntien muuttoliikkeessä, johtuu nähtävästi siitä, että Pyhäranta ja Pyhämaa sijaitsevat lähellä Raumaa ja Uuttakaupunkia sekä Mynämäki lähellä Turkua. Teollisuuskunnissa vaikuttavat asiaan myös väestön kielisuhteet. Ruotsinkielinen väestö, joka niissä on enemmistönä, ei sanottavammin muuta 


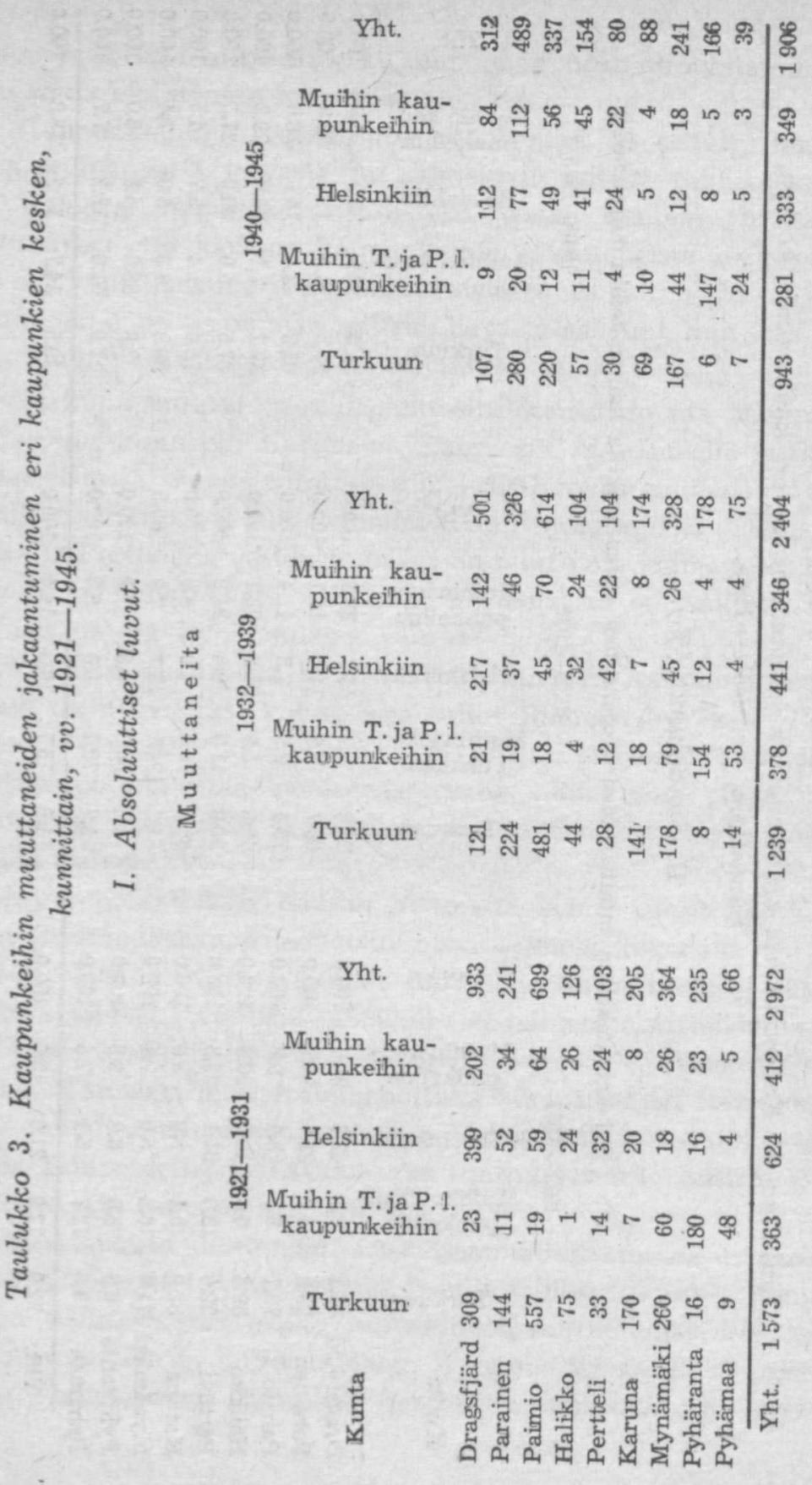




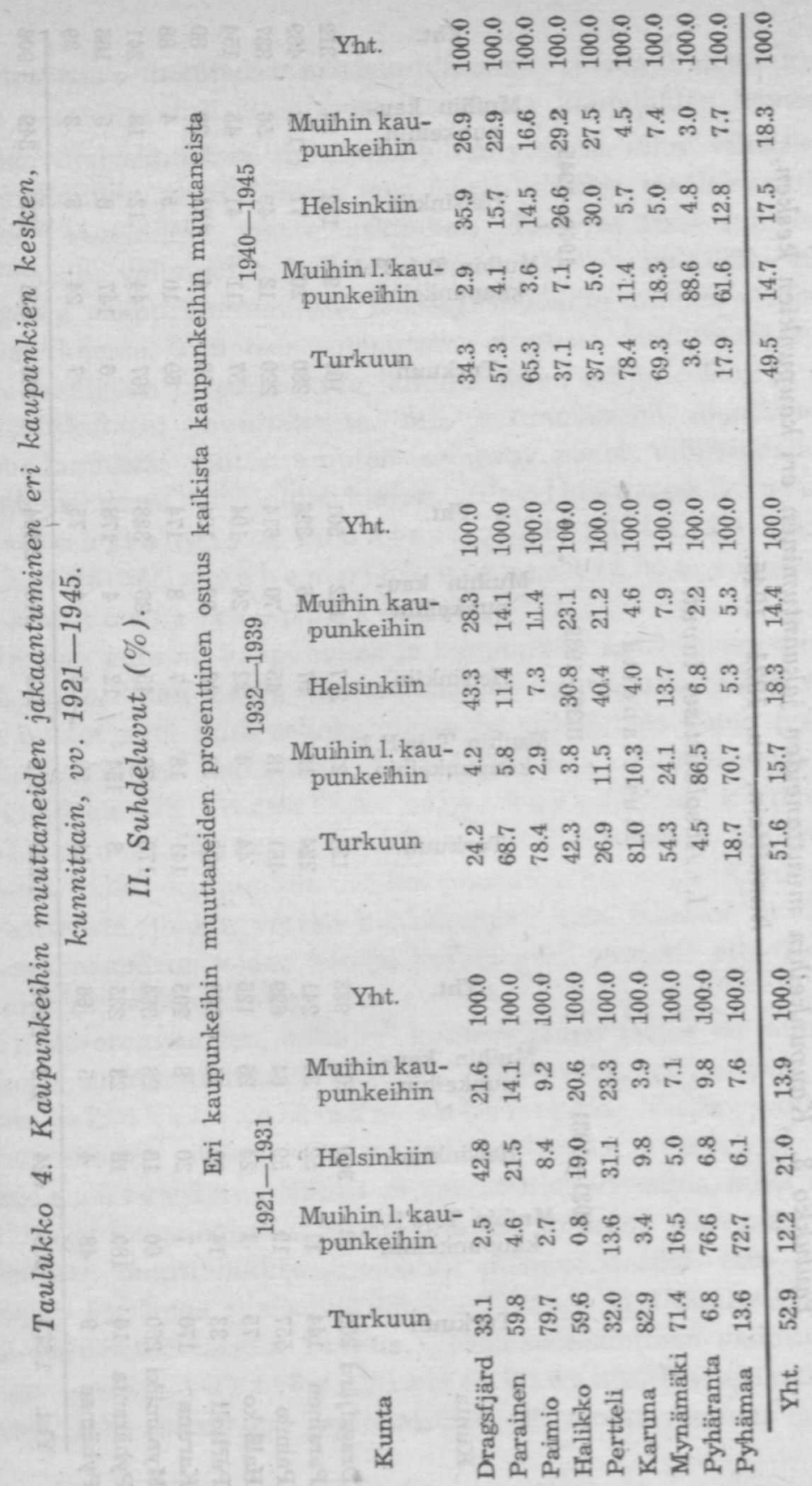


mantereen suomenkielisiin kuntiin, vaan hakeutuu mieluummin kauemmaksi, etenkin kaupunkeihin.

Kaupunkeihin suuntautunut muuttoliike on eritelty tarkemmin taulukossa 3 , ja vastaavat suhdeluvut esitetty taulukossa 4.

Viimeksi mainitussa taulukossa olevat kuntien yhteisluvut osoittavat, että kaikista kaupunkeihin muuttaneista noin puolet on siirtynyt Turkuun ja suunnilleen viidennes Helsinkiin. Näiden kaupunkien osuus on ajan mittaan lievästi laskenut, kun taas muihin kaupunkeihin muutto on vastaavasti vilkastunut.

Turkuun muutto on ollut suhteellisesti suurin sitä lähinnä sijaitsevissa kunnissa: Karunassa, Paimiossa, Mynämäellä ja Paraisilla. Näissä samoin kuin vv. 1921-1931 myös Halikossa Turun osalle on tullut yli puolet kaupunkeihin muuttajista. Dragsfjärdissä ja Perttelissä vastaava määrä on ollut noin kolmannes, 1930luvulla kuitenkin vain neljännes, Pyhämaassa suunnilleen kuudennes, mutta Pyhärannassa vain 4-7\%.

Viimeksi mainitusta kunnasta tapahtuneista kaupunkiin muutoista on noin kaksi kolmasosaa tullut Rauman hyväksi. Pyhämaassa vastaava luku on melkein puolta pienempi, sillä sieltä Uusikaupunki vetää puoleensa väkeä miltei yhtä paljon kuin Raumakin. Myöskin Mynämäeltä muutetaan Uuteenkaupunkiin melko paljon.

Näitä poikkeuksia lukuun ottamatta läänin muut kaupungit ovat tutkimuksemme kohdekunnissa jääneet kokonaan varjoon Turun rinnalla. Mutta muiden läänien vaikutus alkaa jo tuntua Salon seuduilla. Vv. 1932-1939 oli Helsinkiin muuttaneiden osuus Halikossa 31, Perttelissä 40 ja Dragsfjärdissä $43 \%$. Viimeksi mainitusta kunnasta muutettiin sanottuna aikana paljon Hankoonkin (108 henkilöä eli puolet siitä mitä Helsinkiin) ja vv. 1921-1931 myös Tampereelle, jonka vaikutus tuntuu jossakin määrin myös Halikossa ja muissakin kunnissa.

Muttovoitto ja -tappio. Aikaisemmin mainitussa tutkimuksessa on jo osoitettu, miten Dragsfjärdin teollisuuskunnan muuttotappio nousi vv. 1921-1931 suhteellisesti suuremmaksi kuin minkään muun Turun ja Porin läänin kunnan. Syynä oli lähinnä se, että Taalintehtaan työväkeä jouduttiin vähentämään, ensinnä 
1920-luvun alkupuolella rationalisoinnin, sitten vuosikymmenen lopulla pulakauden takia. Tämän vuoksi myös tutkimuksemme kohdekuntien yhteiset luvut sanotulta ajalta osoittavat melkoista muuttotappiota. Vain sekakuntien ja niiden naapurikuntien välinen muuttoliike muodostui tällöin edellisille muuttovoittoiseksi (taulukko 1).

Toisin oli asian laita 1930-luvulla. Nyt teollisuuskunnat voittivat väkeä sekä naapurikunnilta että muilta saman läänin maalaiskunnilta ja menettivät sitä tosiasiallisesti vain kaupungeille. Muiden kuntaryhmien osalta kiintyy huomio erikoisesti siihen seikkaan, että niin hyvin sekakunnat kuin varsinaiset maatalousja pienviljelyskunnatkin saivat vv. 1932-1939 muuttovoittoa muiden läänien maalaiskunnista. Tämä muualta tuleva väestönvirtaus voimistui edelleen sotavuosina, lähinnä kai siirtoväen ansiosta. Tutkimuksemme kohdekuntien yhteinen muuttotappio kaupungeille oli ajanjaksoina $1932-1939$ ja $1940-1945$ suurempi kuin niiden koko muuttotappio. Toisin sanoen niiden muuttoliike muiden maalaiskuntien kanssa muodostui tällöin muuttovoittoiseksi.

Kaikki nämä kunnat ovat siis suuremmassa tai pienemmässä määrässä väliasemia kaupunkeihin suuntautuvassa muuttoliikkeessä. Erikoisesti on näin laita teollistuneimpiin kuntiin nähden. Sen käsityksen paikkansapitävyys, että maaseudun teollisuuskunnat kykenisivät toimimaan »maaltapaon» estäjinä, on näin ollen kyseenalainen. Niiden saama muuttovoitto on omiaan herättämään sen virheellisen ajatuksen, että ko. väestömäärä on niiden ansiosta estynyt siirtymästä kaupunkeihin. Todellisuudessa teollisuuskunnat näyttävät olevan vain eräänlaisia imukuppeja, jotka vetävät puoleensa lähiseudun maatalousväestöä, joka sitten niiden kautta kulkeutuu kaupunkeihin saatuaan niissä ensinnä alustavan koulutuksen teollisuustyöhön. Kuten edellä jo on osoitettu (s. 3), teollisuuskuntien muuttoliike on suuntautunut pääasiallisesti kaupunkeihin ja sen ohella myös jossakin määrin maaseudun teollisuuskeskuksiin. Mikäli tällaisella teollisuuspaikkakunnalla on riittävät kehittymi- 
sen edellytykset, siitä itsestä kasvaa ennen pitkää kaupunki, ellei nimellisesti, niin ainakin tosiasiallisesti.

Muuttaneiden sukupuoli. Taulukko 5 osoittaa muuttoliikkeen paikallisen jakaantumisen toisaalta miespuolisten, toisaalta naispuolisten muuttaneiden osalta.

Kuntien yhteislukujen perusteella voidaan todeta, että naiset ovat aina olleet suhteellisesti runsaammin edustettuina kaupungeista ja Turun ja Porin läänin ulkopuolisista maalaiskunnista tulleessa muuttoliikkeessä, miehet taas naapurikunnista ja muista oman läänin maalaiskunnista tapahtuneissa muutoissa. Myöskin kaupunkeihin muutto on aina saavuttanut laajemmat mittasuhteet naisten kuin miesten keskuudessa. Varsinkin vv. 1932-1939 erotus oli tässä suhteessa suuri: kaikista kunnasta muuttaneista naisista siirtyi kaupunkeihin lähes $27 \%$, miehistä vastaavasti $22 \%$. Naapurikuntiin muutossa sen sijaan molemmat sukupuolet olivat rauhan vuosina edustetut jotenkin yhtä hyvin, kun taas muihin maalaiskuntiin miehiä tavallisesti muutti suhteellisesti jonkin verran enemmän kuin naisia.

Yksityisten kuntaryhmien luvut osoittavat seuraavaa:

Sekä k a u p ung e is t a että kaupunkeihin muutto on yleensä ollut teollisuus- ja sekakunnissa naisten osalta suhteellisesti suurempi kuin miesten. Samoin oli asianlaita vv. 1932-1939 muissakin kuntatyypeissä.

$\mathrm{Na}$ a purikunnista muutto on ollut naisten osalta suhteellisesti suurempi vain pienviljelyskunnissa, sota-aikana myöskin varsinaisissa maatalouskunnissa. Päinvastaiseen muuttoliikkeeseen nähden tilanne on ollut suurin piirtein sama.

Läänin muista maalaiskunnista muutto on tavallisesti ollut miesten osalta vilkkдampaa kaikissa kuntaryhmissä, ja samoin oli rauhan vuosina asian laita myös päinvastaiseen muuttojiikkeeseen nähden.

Paria vähäistä sotavuosina sattunutta poikkeusta lukuunottamatta muiden läänien maalaiskunnista on naisia muuttanut suhteellisesti runsaammin kuin miehiä kaikkiin ko. kuntaryhmiin. Miehistä taas on tavallisesti tullut suurempi prosenttimäärä päinvastaisen muuttoliikkeen osalle. 
Taulukko 5. Muuttaneiden prosenttinen jakaantuminen lähtö- ja päätepaikan perusteella kuntaryhmittäin ja sukupuolen mukaan vv. 1921-45.

\section{Kuntaan muttaneet}

$\begin{array}{cccccc}\begin{array}{c}\text { Ajanjakso ja } \\ \text { kuntaryhmä }\end{array} & \begin{array}{c}\text { Kaupun- } \\ \text { geista }\end{array} & \begin{array}{c}\text { Naapuri- } \\ \text { kunnista }\end{array} & \begin{array}{c}\text { Saman l, } \\ \text { muista } \\ \text { kunnista }\end{array} & \begin{array}{c}\text { Maan muista } \\ \text { mlk:ista }\end{array} & \text { Yht. } \\ & \text { Mp. Np. } & \text { Mp. Np. } & \text { Mp. Np. } & \text { Mp. Np. }\end{array}$

\begin{tabular}{lrrrrrrrrr} 
1921_1931: & & & & & & & & \\
Teollisuuskunnat $\ldots$ & 20.7 & 24.3 & 43.3 & 40.7 & 22.1 & 20.0 & 13.9 & 15.0 & 100.0 \\
Sekakunnat ....... & 10.9 & 11.9 & 38.8 & 37.2 & 40.8 & 39.0 & 9.5 & 11.9 & 100.0 \\
Varsin.maatalousk. ... & 6.0 & 5.3 & 49.0 & 46.0 & 34.9 & 35.4 & 10.1 & 13.3 & 100.0 \\
Pienvilj.kunnat ..... & 13.6 & 12.5 & 46.8 & 49.9 & 33.6 & 30.7 & 6.0 & 6.9 & 100.0 \\
\hline Yhteensä & 12.1 & 12.8 & 43.7 & 42.7 & 34.5 & 32.9 & 9.7 & 11.6 & 100.0
\end{tabular}
1932-1939:

\begin{tabular}{rrrrrrrrrr} 
Teollisuuskunnat $\ldots$. & 30.4 & 38.7 & 40.2 & 30.3 & 15.8 & 15.3 & 13.6 & 15.7 & 100.0 \\
Sekakunnat $\ldots \ldots . .$. & 10.4 & 12.4 & 34.7 & 31.4 & 40.9 & 38.7 & 14.0 & 17.5 & 100.0 \\
Varsin maatalousk. .. & 4.7 & 6.4 & 34.9 & 32.4 & 43.6 & 42.2 & 16.8 & 19.0 & 100.0 \\
Pienvilj.kunnat ..... & 13.7 & 14.0 & 42.9 & 44.5 & 35.2 & 31.4 & 8.2 & 10.1 & 100.0 \\
\hline Yhteensä & 13.4 & 16.3 & 37.4 & 34.3 & 35.8 & 33.6 & 13.4 & 15.8 & 100.0
\end{tabular}

$$
\text { 1940-1945: }
$$

$\begin{array}{llllllllllll}\text { Teollisuuskunnat } & \ldots & 34.6 & 44.5 & 28.3 & 21.1 & 16.7 & 14.1 & 20.4 & 20.3 & 100.0\end{array}$

$\begin{array}{lllllllllll}\text { Sekakunnat } \ldots \ldots \ldots & 12.5 & 15.5 & 27.8 & 24.2 & 36.6 & 36.4 & 23.1 & 23.9 & 100.0\end{array}$

$\begin{array}{llllllllll}\text { Varsin. maatalousk. .. } & 10.2 & 10.1 & 32.6 & 33.4 & 31.1 & 30.9 & 26.1 & 25.7 & 100.0\end{array}$

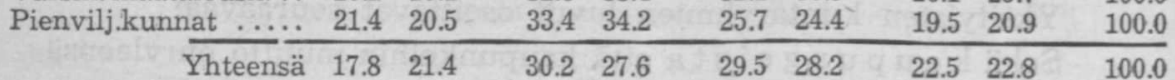

Kunnasta muttaneet

$\begin{array}{cccccc}\begin{array}{c}\text { Ajanjakso ja } \\ \text { kuntaryhmä }\end{array} & \begin{array}{c}\text { Kaupun- } \\ \text { keihin }\end{array} & \begin{array}{c}\text { Naapuri- } \\ \text { kuntiin }\end{array} & \begin{array}{c}\text { Saman 1. } \\ \text { muihin } \\ \text { kuntiin }\end{array} & \begin{array}{c}\text { Maan muihin } \\ \text { mlk:iin }\end{array} & \text { Yht. } \\ & \text { Mp. Np. } & \text { Mp. Np. } & \text { Mp. Np. } & \text { Mp. Np. }\end{array}$

1921-1931:

\begin{tabular}{rrrrrrrrrr} 
Teollisuuskunnat $\ldots$ & 42.7 & 47.0 & 29.5 & 29.1 & 13.9 & 11.9 & 13.9 & 12.0 & 100.0 \\
Sekakunnat ...... & 23.2 & 22.6 & 30.8 & 30.9 & 34.1 & 36.2 & 11.9 & 10.3 & 100.0 \\
Varsin. maatalousk. ... & 10.8 & 14.7 & 40.9 & 38.1 & 38.0 & 37.7 & 10.3 & 9.5 & 100.0 \\
Pienvilj.kunnat .... & 25.5 & 22.5 & 32.8 & 35.9 & 35.2 & 35.2 & 6.5 & 6.4 & 100.0 \\
\hline Yhteensä & 25.5 & 26.5 & 33.1 & 33.2 & 30.6 & 30.8 & 10.8 & 9.5 & 100.0 \\
\hline
\end{tabular}
1932-1939:

$\begin{array}{llllllllllll}\text { Teollisuuskunnat } & \ldots & 47.3 & 56.5 & 20.9 & 20.5 & 12.8 & 10.5 & 19.0 & 12.5 & 100.0\end{array}$

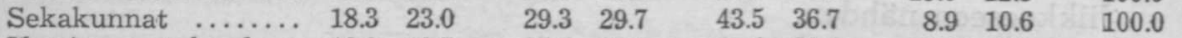

$\begin{array}{llllllllll}\text { Varsin.maatalousk. .. } & 10.9 & 12.5 & 35.5 & 35.5 & 39.4 & 38.8 & 14.2 & 13.2 & 100.0\end{array}$

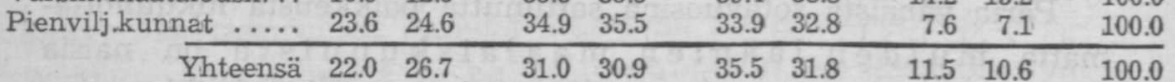

1940-1945:

\begin{tabular}{|c|c|c|c|c|c|c|c|c|c|}
\hline uuskunnat & 50.0 & 53.6 & 16.9 & 16.9 & 16.0 & 14.0 & 17.1 & 15.5 & \\
\hline Sekakunnat & 19 & 20 & 33.4 & 27 & 31.9 & 3. & 15.4 & & 10 \\
\hline Varsin. maatalousk. & 15.2 & 12. & 31.9 & 32. & 32.1 & 34 & 20.8 & 20 & 100.0 \\
\hline lj.kunnat. & 3. & 32 & 0 & 30.0 & 20.2 & 26.2 & 10.3 & 11.0 & 100.0 \\
\hline Yhtee & 28.6 & 29.5 & 28.6 & 26.4 & 26.9 & 28.0 & 15.9 & 16.1 & 00.0 \\
\hline
\end{tabular}


Tutkimuksemme kohdekunnat vetävät siis puoleensa naisia varsinkin Turun ja Porin läänin ulkopuolella sijaitsevista maalaiskunnista, jossakin määrin myös kaupungeista. Viimeksi mainittu seikka johtunee kuitenkin lähinnä takaisin muutoista, sillä myöskin kaupunkeihin muutto on ollut vilkasta naisten osalta. Niinikään voidaan todeta, ettei lähimuuttoja voida pitää minään erikoisesti naisille ominaisena muuton lajina, kuten eräissä aikaisemmissa ulkomaiden oloja koskevissa tutkimuksissa on esitetty, ${ }^{3}$ vaan että asian laita ainakin ko. kunnissa ja sanottuna aikana on pikemminkin ollut päinvastainen.

\section{Muuffaneiden syntymäpaikka.}

Taulukossa 6 on muuttaneiden lähtö- ja päätekohdan ohella otettu huomioon myöskin heidän syntymäpaikkansa, minkä perusteella heidät on jaettu kolmeen ryhmään. Nämä ovat:

1. poismuuttaneet, s.o. syntymäkunnastaan pois muuttaneet,

2. takais in mu ut ta n e et: syntymäkuntaansa palanneet, ja

3. edelleen muttaneet: ne, jotka ovat syntyneet jossakin muussa kunnassa kuin siinä, josta tai johon muutto tapahtuu.

Ryhmittelyssä on otettu huomioon vain itsenäiset henkilöt, so. sellaiset joiden muutto ei - sikäli kuin voidaan päätellä - ole johtunut perheen muiden jäsenten muutosta, vaan jotka omasta aloitteestaan ovat siirtyneet toiselle paikkakunnalle. Tällaisiả ovat perheiden päähenkilöt sekä yksin muuttavat työkykyiseen ikään ehtineet miehet ja naiset. Mukaan ei ole otettu 15 vuotta nuorempia lapsia, vaikka he olisivatkin muuttaneet yksin, ei liioin yhdessä muuttavan perheen jäsenistä muita kuin sen päämies.

Taulukko 7 osoittaa, suuriko kunkin äsken mainitun ryhmän prosenttinen osuus on eri ajanjaksoina ollut muuttajien kokonaismäärästä. Tutkimuskuntien yhteislukujen mukaan syntymäkunrastaan poismuuttaneiden määrä on jatkuvasti alentunut, kun 
Taulukko 6. Pois-, takaisin ja edelleen muuttaneet kuntaryhmittäin vv. $1923-1925,1933-1935$ ja $1943-1945$.

Kuntaan muttaneet

Ajanjakso ja kuntaryhmä 1923-1925:
Takaisin Edelleen

Pois-

muuttaneet

Mp. Np. Yht. muuttaneet

Mp. Np. Yht. muuttaneet

$\begin{array}{lrrrrr}19 & 22 & 41 & 122 & 66 & 188\end{array}$

$\begin{array}{lllllll}56 & 38 & 94 & 184 & 74 & 258\end{array}$

$\begin{array}{llllll}10 & 10 & 20 & 31 & 12 & 43\end{array}$

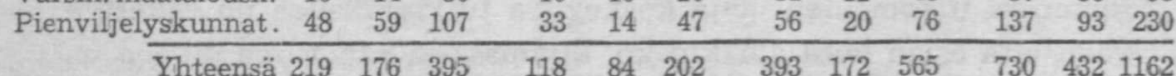

1933-1935:

$\begin{array}{lllllllllllll}\text { Teollisuuskunnat } & 73 & 56 & 129 & 84 & 76 & 160 & 134 & 113 & 247 & 291 & 245 & 536\end{array}$

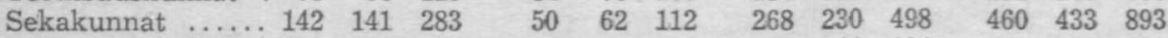

$\begin{array}{lllllllllllll}\text { Varsin.maatalousk. } & 32 & 12 & 44 & 8 & 15 & 23 & 60 & 44 & 104 & 100 & 71 & 171\end{array}$

\begin{tabular}{lllllllllllll} 
Pienviljelyskunnat. 59 & 60 & 119 & 43 & 54 & 97 & 94 & 71 & 165 & 196 & 185 & 381 \\
\hline
\end{tabular}

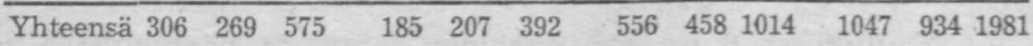

1943-1945:

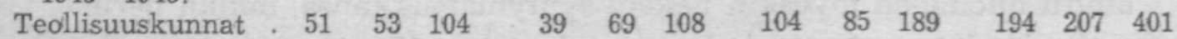

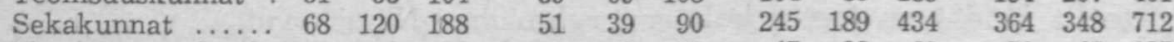

$\begin{array}{lllllllllllll}\text { Varsin.maatalousk. } & 20 & 16 & 36 & 12 & 10 & 22 & 47 & 22 & 69 & 79 & 48 & 127\end{array}$

\begin{tabular}{lllllllllllll} 
Pienviljelyskunnat. & 63 & 60 & 123 & 30 & 46 & 76 & 94 & 67 & 161 & 187 & 173 & 360 \\
\hline
\end{tabular}

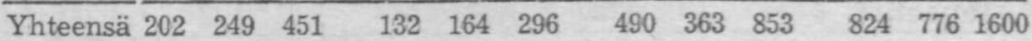

Kunnasta muttaneet

Ajanjakso ja kuntaryhmä 1923-1925:

Teollisuuskunnat $\quad 118 \quad 98 \quad 216$

Sekakunnat ....... $124 \quad 103 \quad 227$

Varsin. maatalousk. $48 \quad 45 \quad 93$

Pienviljelyskunnat. $97 \quad 76 \quad 173$
Takaisin Edelleen

muuttaneet muuttaneet

Mp. Np. Yht. Mp. Np. Yht. Mp. Np. Yht.

$\begin{array}{lllllllll}20 & 8 & 28 & 128 & 57 & 185 & 266 & 163 & 429\end{array}$

$\begin{array}{llllllllll}53 & 25 & 78 & 191 & 113 & 304 & 368 & 241 & 609\end{array}$

$\begin{array}{lllllllll}23 & 9 & 32 & 82 & 38 & 120 & 153 & 92 & 245\end{array}$

$\begin{array}{lll}15 & 14 & 29\end{array}$

$\begin{array}{lll}111 & 56 & 167\end{array}$

$\begin{array}{lll}56 & 27 & 83\end{array}$

Yhteensä $\begin{array}{lllllllll}387 & 322 & 709 & 111 & 56 & 167 & 457 & 235 & 692\end{array}$

1933-1935:

Teollisuuskunnat. $\begin{array}{llllllllllll}120 & 207 & 327 & 28 & 30 & 58 & 126 & 110 & 236 & 274 & 347 & 621\end{array}$

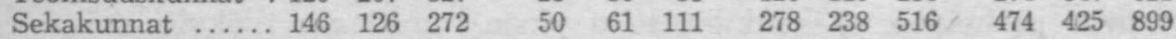

$\begin{array}{lllllllllllll}\text { Varsin. maatalousk. } & 72 & 71 & 143 & 28 & 24 & 52 & 94 & 93 & 187 & 194 & 188 & 382\end{array}$

Pienviljelyskunnat. \begin{tabular}{llllllllllll}
141 & 124 & 265 & 24 & 43 & 67 & 83 & 75 & 158 & 248 & 242 & 490 \\
\hline
\end{tabular}

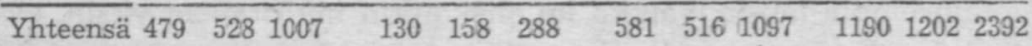

1943-1945:

$\begin{array}{lllllllllllll}\text { Teollisuuskunnat } & 162 & 157 & 319 & 40 & 46 & 86 & 201 & 115 & 316 & 403 & 318 & 721\end{array}$

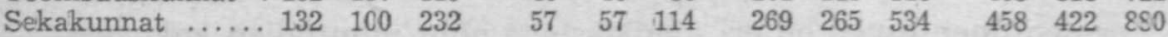

$\begin{array}{lllllllllllll}\text { Varsin.maatalousk. } & 57 & 55 & 112 & 13 & 13 & 26 & 67 & 57 & 124 & 137 & 125 & 262\end{array}$

\begin{tabular}{lllllllllllll} 
Pienviljelyskunnat. & 86 & 111 & 197 & 23 & 28 & 51 & 74 & 85 & 159 & 183 & 224 & 407 \\
\hline
\end{tabular}

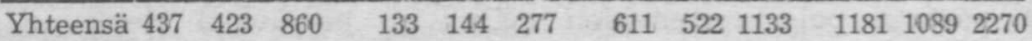


Taulukko 7. Pois-, takaisin ja edelleen muuttaneiden prosenttinen osuus kaikista muuttaneista vv. 1923-25, 1933-35 ja 1943-45.

Ajanjakso ja

kuntaryhmä

1923-1925:

Teollisuuskunnat

Sekakunnat ..........

Varsin maatal.kunnat

Pienviljelyskunnat ...

Kuntaan mutto

\begin{tabular}{lllllllllll}
\hline Yhteensä & 30.0 & 40.8 & 34.0 & 16.2 & 19.4 & 17.4 & 53.8 & 39.8 & 48.6 & 100.0
\end{tabular}

1933-1935:

$\begin{array}{llllllll}\text { Teollisuuskunnat } & \ldots & 25.1 & 22.9 & 24.1 & 28.9 & 31.0 & 29.8\end{array}$

$\begin{array}{llllllll}\text { Sekakunnat } \ldots \ldots \ldots \ldots & 30.9 & 32.6 & 31.7 & 10.9 & 14.3 & 12.5\end{array}$

$\begin{array}{lllllll}\text { Varsin. maatal.kunnat } & 32.0 & 16.9 & 25.7 & 8.0 & 21.1 & 13.4\end{array}$

$\begin{array}{llllllll}\text { Pienviljelyskunnat } & \ldots & 30.1 & 32.4 & 31.2 & 21.9 & 29.2 & 25.5\end{array}$

\begin{tabular}{lllllll}
\hline Yhteensä & 29.2 & 28.8 & 29.0 & 17.7 & 22.2 & 19.8
\end{tabular}

$\begin{array}{llll}46.0 & 46.1 & 46.1 & 100.0\end{array}$

$\begin{array}{llll}58.2 & 53.1 & 55.8 & 100.0\end{array}$

$\begin{array}{llll}60.0 & 62.0 & 60.9 & 100.0\end{array}$

$\begin{array}{llll}48.0 & 38.4 & 43.3 & 100.0\end{array}$

$\begin{array}{llll}53.1 & 49.0 & 51.2 & 100.0\end{array}$

1943-1945:

$\begin{array}{llllllllllll}\text { Teollisuuskunnat } & \ldots & 26.3 & 25.6 & 25.9 & 20.1 & 33.3 & 26.9 & 53.6 & 41.1 & 47.2 & 100.0\end{array}$

$\begin{array}{llllllllllll}\text { Sekakunnat } \ldots \ldots \ldots \ldots & 18.7 & 34.5 & 26.4 & 14.0 & 11.2 & 12.6 & 67.3 & 54.3 & 61.0 & 100.0\end{array}$

$\begin{array}{lllllllllll}\text { Varsin. maatal.kunnat } & 25.3 & 33.3 & 28.3 & 15.2 & 20.8 & 17.3 & 59.5 & 45.8 & 54.4 & 100.0\end{array}$

\begin{tabular}{llllllllllll} 
Pienviljelyskunnat &.. & 33.7 & 34.7 & 34.2 & 16.0 & 26.6 & 21.1 & 50.3 & 38.7 & 44.7 & 100.0 \\
\hline
\end{tabular}

\begin{tabular}{lllllllllll}
\hline Yhteensä & 24.5 & 32.1 & 28.2 & 16.0 & 21.1 & 18.5 & 59.5 & 46.8 & 53.3 & 100.0
\end{tabular}

Ajanjakso ja

kuntaryhmä

1923-1925:

Teollisuuskunnat

$\begin{array}{lllll} & & & \end{array}$

Varsin. maatal.kunnat $\begin{array}{llll}31.3 & 48.9 & 38.0\end{array}$

$\begin{array}{llllll}\text { Pienviljelyskunnat } & . . & 57.8 & 65.0 & 60.7\end{array}$

Kunnasta mutto

Pois-

muuttaneet

muuttaneet

muuttaneet

$\begin{array}{lll}7.5 & 4.9 & 6.5\end{array}$

$\begin{array}{lll}14.4 & 10.4 & 12.8\end{array}$

$\begin{array}{lll}15.0 & 9.8 & 13.0\end{array}$

$\begin{array}{lll}8.9 & 12.0 & 10.2\end{array}$

Edelleen

Yhit.

muuttaneet

Mp. Np. Yht.

$\begin{array}{llll}48.1 & 35.0 & 43.2 & 100.0\end{array}$

$\begin{array}{llll}51.9 & 46.9 & 49.9 & 100.0\end{array}$

$\begin{array}{llll}53.7 & 41.3 & 49.0 & 100.0\end{array}$

\begin{tabular}{llll}
33.3 & 23.0 & 29.1 & 100.0 \\
\hline
\end{tabular}

\begin{tabular}{lllllllllll}
\hline Yhteensä & 40.5 & 52.6 & 45.2 & 11.6 & 9.1 & 10.7 & 47.9 & 38.3 & 44.1 & 100.0
\end{tabular}

1933-1935:

$\begin{array}{llllllllllll}\text { Teollisuuskunnat } & \ldots & 43.8 & 59.7 & 52.7 & 10.2 & 8.6 & 9.3 & 46.0 & 31.7 & 38.0 & 100.0\end{array}$

$\begin{array}{llllllllllll}\text { Sekakunnat } \ldots \ldots \ldots \ldots & 30.8 & 29.6 & 30.3 & 10.5 & 14.3 & 12.3 & 58.7 & 56.1 & 57.4 & 100.0\end{array}$

$\begin{array}{llllllllllll}\text { Varsin. maatal.kunnat } & 37.1 & 37.8 & 37.4 & 14.4 & 12.8 & 13.6 & 48.5 & 49.4 & 49.0 & 100.0\end{array}$

\begin{tabular}{lllllllllllll} 
Pienviljelyskunnat & $\ldots$ & 56.8 & 51.2 & 54.1 & 9.7 & 17.8 & 13.7 & 33.5 & 31.0 & 32.2 & 100.0 \\
\hline
\end{tabular}

\begin{tabular}{lllllllllll}
\hline Yhteensä & 40.3 & 43.9 & 42.1 & 10.9 & 13.2 & 12.0 & 48.8 & 42.9 & 45.9 & 100.0
\end{tabular}

1943-1945:

$\begin{array}{lllllllllllll}\text { Teollisuuskunnat } & \ldots & 40.2 & 49.4 & 44.2 & 9.9 & 14.5 & 11.9 & 49.9 & 36.1 & 43.9 & 100.0\end{array}$

$\begin{array}{llllllllllll}\text { Sekakunnat } \ldots \ldots \ldots \ldots & 28.9 & 23.7 & 26.4 & 12.4 & 13.5 & 12.9 & 58.7 & 62.8 & 60.7 & 100.0\end{array}$

$\begin{array}{lllllllllll}\text { Varsin. maatal.kunnat } & 41.6 & 44.0 & 42.7 & 9.5 & 10.4 & 9.9 & 48.9 & 45.6 & 47.4 & 100.0\end{array}$

\begin{tabular}{lllllllllllll} 
Pienviljelyskunnat &.. & 47.0 & 49.6 & 48.4 & 12.6 & 12.5 & 12.5 & 40.4 & 37.9 & 39.1 & 100.0 \\
\hline
\end{tabular}

$\begin{array}{lllllllllll}\text { Yhteensä } & 37.0 & 38.8 & 37.9 & 11.3 & 13.3 & 12.2 & 51.7 & 47.9 & 49.9 & 100.0\end{array}$ 
taas edelleen mu uttaneiden osuus on kasvanut, olipa sitten kysymyksessä muualta tutkimuskuntiin tai tutkimuskunnista muualle tapahtuneet muutot. Myöskin syntymäkuntaansa takaisin muuttaneiden osuus on yleensä noussut.

Tämä kehityksen suunta on kuitenkin pääasiallisesti naisten ansiota. Miesten jakaantuminen kolmen ko. ryhmän kesken oli kumpanakin sotienvälisenä ajanjaksona, so. vuosina 1923-1925 ja 1933-1935 jotenkin sama. Naisten osalta sen sijaan poismuuttaneiden suhdeluku aleni tällä välin kuntaan muuttoon nähden 41:stä $29 \%$ :iin ja kunnasta muuttoon nähden 53:sta $44 \%$ :iin muiden ryhmien vastaavasti suurentuessa. Seurauksena oli, että se huomattava erotus, mikä miesten ja naisten suhdelukujen välillä on todettavissa vv. 1923-1925, oli kymmenen vuotta myöhemmin suurelta osalta tasoittunut. Tämä tasoittumispyrkimys jatkui vv. 1943-1945 tutkimuskunnista tapahtuneen muuton osalta, kun taas muualta niihin suuntautuneessa muuttoliikkeessä eri sukupuolten suhdelukujen välinen erotus jälleen suureni. Tähän lienee vaikuttanut osaksi siirtoväki, osaksi se seikka, että nuoret miehet eivät sodan takia voineet osallistua muuttoliikkeeseen samassa määrin kuin aikaisemmin.

Naiset ovat yleensä olleet suhteellisesti runsaammin edustetut syntymäkunnastaan poismuuttaneiden ja sinne takaisin muuttaneiden ryhmissä, miehet taas edelleen muuttaneiden ryhmässä. Tämä johtuu lähinnä siitä, että nuoria ja naimattomia on suhteellisesti enemmän naisten kuin miesten joukossa. Taulukoiden 6 ja 7 lukuihin eivät näet sisälly ne perheenäidit, jotka ovat muuttaneet yhdessä miehensä kanssa.

Tilanteesta erityyppisissä kunnissa antavat parhaan kuvan niistä muualle suuntautunutta muuttoliikettä koskevat luvut. Niiden mukaan poismuutto on aina ollut pienviljelys- ja teollisuuskunnissa tuntuvasti suurempi kuin varsinaisissa maatalous- ja sekakunnissa, kun taas edelleenmuuttoon nähden asian laita on ollut päinvastainen. Edelleenmuuton vilkkaus viimeksi mainituissa kuntatyypeissä johtuu siitä, että näissä kunnissa on runsaasti keski- ja suurviljelmiä, joiden maataloustyöväestö ahkerasti siirtyy talosta ja kunnasta toiseen. Myöskin teollisuuskunnissa 
edelleenmuutto on yleistä miesten keskuudessa. Teollisuuskunnista muuttaneista naisista sen sijaan tuli rauhan vuosina $60 \%$ poismuuttaneiden ryhmän osalle, mikä viittaa siihen, että näissä kunnissa oli puutetta naisille sopivista työtilaisuuksista. Samoin näyttää asian laita olleen pienviljelyskunnissakin sekä miehiin että naisiin nähden.

\section{Yhdistävä yleiskatsaus.}

Edellä selostettu tutkimus osoittaa muuttojen pituuden ko. aikana kasvaneen. Tämä ilmenee siinä, että naapurikuntien välinen muuttoliike on supistunut, kun taas etäisempiin kuntiin ja etenkin kaupunkeihin suuntautuneet muutot ovat lisääntyneet. Erikoisen vilkasta on ollut kaupunkien ja teollisuuskuntien välinen muuttoliike. Tämä on tietysti johtunut lähinnä niiden elinkeinoelämän yhdenmukaisuudesta, etenkin siitä suuresta merkityksestä mikä teollisuudella on kummassakin kuntaryhmässä. Osaksi on asiaan vaikuttanut sekin seikka, että ko. teollisuuskuntien ruotsinkielinen väestö on muuttanut mieluummin kaupunkeihin kuin suomenkielisiin lähikuntiin.

Tutkimuksemme kohteena olevat kunnat ovat 1930- ja 1940-luvuilla voittaneet väkeä etenkin läänin ulkopuolella sijaitsevista maalaiskunnista. Sotavuosina tätä muuttoliikettä lisäsi siirtoväki, mutta jo rauhan vuosinakin oli tällainen virtaus selvästi havaittavissa. Nähtävästi toimeentulon mahdollisuudet ovat olleet tutkimuksemme kohdekunnissa siksi hyvät, että nämä kunnat ovat kyenneet vetämään puoleensa väkeä maan muista lääneistä. Kokonaisuudessaankin näiden kuntien vãestönvaihto muiden maalaiskuntien kanssa - muut Turun ja Porin läänin maalaiskunnat näihin luettuina - on vv. 1932-1945 muodostunut muuttovoittoiseksi. Tähän muuttovoittoon verrattuna niiden muuttotappio kaupungeille on kuitenkin ollut moninkertainen. Nämä kunnat ovat siis toimineet eräänlaisina maaseudulta kaupunkeihin suuntautuvan muuttoliikkeen kauttakulkuasemina.

Naiset ovat olleet suhteellisen runsaasti edustetut etenkin läänin ulkopuolelta saapuneiden sekä kaupunkeihin muuttaneiden 
ryhmissä. Matkan pituus ei näytä olevan heille sen pahempana muuton esteenä kuin miehillekään.

Huomattava osa muutoista on kuitenkin lyhytmatkaisia. 1930luvulla noin kolmas osa muuttotapauksista tuli naapurikuntien osalle. Sen vuoksi myös kaupunkeihin muuton kysymyksessä ollen lähin kaupunki tavallisesti vetää maalaisväestöä puoleensa voimakkaimmin, vaikka se olisi pienikin. Mutta mitä suurempi kaupunki on, sitä laajempi on sen »voimakenttä». Niinpä esim. Turun ja Helsingin puoleensa vetävä vaikutus on selvästi havaittavissa kaikissa ko. kunnissa.

Muuttajien valtava enemmistö on vaihtanut kotikuntaa ainakin jo kerran aikaisemmin. Kaikista tutkimuksemme kohdekuntiin vv. 1943 - 1945 yksin muuttaneista 15 vuotta täyttäneistä henkilöistä tuli syntymäkunnastaan vain $28 \%$, ja heistäkin on osa voinut muuttaa sieltä jo toistamiseen. Ensikertalaisten osuus muuttaneiden koko luvusta on nähtävästi jatkuvasti alentunut, mikä seikka on eräs ilmaus siitä eväestön liikkuvuuden lisääntymisestä, joka maassamme on ollut viime vuosikymmeninä todettavissa.

\section{Lähdeviitteitä.}

1 Lähdeaineiston keräystä ja laatua on selostettu tarkemmin seuraavissa

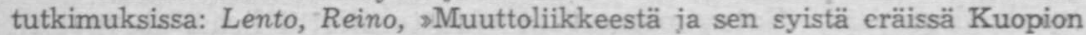
läänin kunnissa vuosina 1921-1944» (Väestöliiton vuosikirja II, Vammala 1948), ss. 100-102, ja „Eräiden Varsinais-Suomen kuntien muuttoliikkeestä vuosina 1921-1945, (Varsinais-Suomen maakuntakirja 11), ss. 58-59.

2 Kuntaryhmityksestä tarkemmin edellä mainitussa Varsinais-Suomen kuntia koskevassa tutkimuksessa ss. $61-64$.

${ }^{3}$ Vrt. esim. Kaila, T. T., sEuropan Venäjän väestönsiirroista XIX. vuosisadan lopullas (Helsinki 1914), s. 103, ja Rauchberg, H., ,Wanderungen in Oesterreichs, Allgem. Stat. Archiv III (Tübingen 1894), s. 197. 